\title{
Dopamine $D_{4}$ receptor activation controls circadian timing of the adenylyl cyclase 1/cyclic AMP signaling system in mouse retina
}

\author{
Chad R. Jackson ${ }^{1}$, Shyam S. Chaurasia ${ }^{2}$, Christopher K. Hwang, and P. Michael luvone ${ }^{3}$ \\ Departments of Ophthalmology and Pharmacology, Emory University School of Medicine, \\ Atlanta, GA, USA 30322
}

\begin{abstract}
In the mammalian retina, dopamine binding to the dopamine $\mathrm{D}_{4}$ receptor affects a light-sensitive pool of cyclic AMP by negatively coupling to the type 1 adenylyl cyclase. The type 1 adenylyl cyclase is the primary enzyme controlling cyclic AMP production in dark-adapted photoreceptors. A previous study demonstrated that expression of the gene encoding the type 1 adenylyl cyclase, Adcyl, is down regulated in mice lacking $\operatorname{Drd4}$, the gene encoding the dopamine $\mathrm{D}_{4}$ receptor. The present investigation provides evidence that dopamine $\mathrm{D}_{4}$ receptor activation entrains the circadian rhythm of Adcyl mRNA expression. Diurnal and circadian rhythms of Drd4 and Adcyl mRNA levels were observed in wild type mouse retina. Also, rhythms in the $\mathrm{Ca}^{2+}$-stimulated adenylyl cyclase activity and cyclic AMP levels were observed. However, these rhythmic activities were damped or undetectable in mice lacking the dopamine $\mathrm{D}_{4}$ receptor. Pharmacologically activating the dopamine $\mathrm{D}_{4}$ receptor $4 \mathrm{hrs}$ before its normal stimulation at light onset in the morning advances the phase of the Adcyl mRNA expression pattern. These data demonstrate that stimulating the dopamine $\mathrm{D}_{4}$ receptor is essential in maintaining the normal rhythmic production of the type 1 adenylyl cyclase from transcript to enzyme activity. Thus, dopamine/dopamine $\mathrm{D}_{4}$ receptor signaling is a novel zeitgeber that entrains the rhythm of Adcyl expression and, consequently, modulates the rhythmic synthesis of cyclic AMP in mouse retina.
\end{abstract}

\section{Keywords}

calmodulin; neuromodulator; entrainment; light; gene expression

\section{Introduction}

Retinal dopamine is synthesized and released from a subset of amacrine and interplexiform cells. Dopamine synthesis and release are stimulated by light. Released dopamine diffuses throughout the retina to activate $\mathrm{D}_{1}$-like and $\mathrm{D}_{2}$-like receptors, each contributing to unique biological processes (reviewed by Witkovsky, 2004). The dopaminergic signaling system is key in retinal processing controlling melatonin production in photoreceptor cells (Tosini et al., 2008), Na/K ATPase activity (Shulman \& Fox, 1996), rod-cone coupling (Ribelayga $e t$ al., 2008), horizontal cell and AII amacrine cell coupling (Baldridge et al., 1998), and light adaptation (Nir et al., 2002).

Several lines of evidence suggest a functional relationship between dopamine and cyclic AMP in the regulation of circadian physiology in the retina. Dopamine $D_{4}$ receptor $\left(D_{4} R\right)$

\footnotetext{
${ }^{3}$ Corresponding author: P.M. Iuvone, Emory Eye Center, 1365B Clifton Road NE, Emory University, Atlanta, GA 30322 USA, miuvone@emory.edu, Phone: 404-727-5989, Fax: 404-727-0365.

${ }^{1}$ Present address: Vanderbilt University, 8268 BSB/MRBIII, $46521^{\text {st }}$ Avenue South, Nashville, TN 37235

${ }^{2}$ Present address: Shyam S. Chaurasia, Singapore Eye Research Institute, Singapore 169612, Singapore
} 
activation suppresses a light-sensitive pool of cyclic AMP in retina (Cohen \& Blazynski, 1990; Cohen et al., 1992) by negatively coupling to the type 1 adenylyl cyclase (AC1), the primary cyclase controlling cyclic AMP production in the dark-adapted mouse retina (Jackson et al. 2009). In chickens and rats, cyclic AMP production in retina fluctuates in a circadian pattern (Ivanova \& Iuvone, 2003; Fukuhara et al., 2004). Cyclic AMP can reset or entrain circadian rhythms in the rat suprachiasmatic nucleus (Prosser \& Gillette, 1989) and Aplysia eye (Eskin, 1982). In mouse retina, dopaminergic amacrine cells co-express the six core circadian clock genes (Gustincich et al., 2004; Ruan et al., 2006; Dorenbos et al., 2007), suggesting this cell contains a functional oscillator. Activation of dopamine $\mathrm{D}_{2}$-like receptors, probably $\mathrm{D}_{4} \mathrm{Rs}$, on Xenopus photoreceptors phase shifts the circadian rhythm of melatonin release (Cahill and Besharse, 1991a). In addition, $D_{1}$ receptor agonists affect the phase of circadian Period 2-driven luciferase (Per2::Luc) rhythms in the inner retina of the mouse (Ruan et al., 2008), and targeted deletion of the $\mathrm{D}_{2}$ receptor gene in mouse decreases light-evoked induction of Perl throughout the retina and dampens the daily rhythm of Perl mRNA levels (Yujnovsky et al., 2006). Thus, dopamine appears to function as a coordinator of circadian retinal physiology.

Dopamine release is stimulated by light in retinas of most vertebrate species (Witkovsky, 2004). In some species, dopamine release is also regulated in a circadian fashion with highest levels during the subjective daytime; however, circadian regulation of dopamine is strain-dependent in mice and related to melatonin synthesis (Nir et al., 2000; Doyle et al., 2002b; Pozdeyev et al., 2008). Mouse strains that make melatonin, such as the $\mathrm{C} 3 \mathrm{H} / \mathrm{f}+/+$, show circadian rhythms of dopamine metabolism that persist in constant darkness, while those that have mutations in the genes that encode enzymes in the melatonin biosynthetic pathway, such as the C57Bl/6, do not (Doyle et al., 2002b; Pozdeyev et al., 2008). Daily injections of melatonin can induce circadian rhythms of dopamine metabolism in C57Bl/6 mice (Doyle et al., 2002b). Diurnal and circadian rhythms of Drd4 mRNA levels have been observed in mouse and rat retina (Storch et al., 2007; Bai et al., 2008; Klitten et al., 2008). Circadian rhythms of Adcyl mRNA, the transcript that encodes AC1, have been observed in retinas of several vertebrate species (Fukuhara et al., 2004; Chaurasia et al., 2006; Storch et al., 2007). Thus, the present study was conducted to investigate a functional role for dopamine and the $\mathrm{D}_{4} \mathrm{R}$ in the circadian regulation of $\mathrm{AC} 1 \mathrm{mRNA}$ expression and enzyme activity in mouse retina, which ultimately controls circadian rhythms of cyclic AMP synthesis.

\section{Materials and Methods}

\section{Animals}

All animal experimental procedures conformed to the guidelines of the National Institutes of Health Guide for the Care and Use of Laboratory Animals and were approved by Emory University's Institutional Animal Care and Use Committee. Mice lacking dopamine $\mathrm{D}_{4}$ receptors (Drd4 $4^{--}$, Rubinstein et al., 1997) and wild-type mice (WT), all on a C57Bl/6 background, were used for this investigation. The $\mathrm{Drd4}^{-/-}$mice were produced by targeted deletion of exon 2. The splicing of exons 1 and 3 caused a frame shift resulting in a premature stop codon. These mice develop normally, have normal retinal morphology and dark-adapted electroretinograms, but have reduced photopic electroretinogram amplitudes (Nir et al., 2002). Mice were approximately 3 months of age. Mice were genotyped by polymerase chain reaction analysis of genomic DNA. Mice were provided food and water ad libitum and were housed on a 12-hour light/dark (LD) cycle with lights on at zeitgeber time (ZT) 0 and lights off at ZT12, unless a lighting schedule change was necessary for specific experimental protocols. Retinal samples were collected at designated ZT or circadian time (CT) points determined by the experimental protocol, immediately frozen on dry ice, and stored at $-80^{\circ} \mathrm{C}$. Circadian rhythms were investigated in mice entrained to the 
LD cycle and subsequently kept in constant ( $24 \mathrm{~h} /$ day) darkness (DD - first day of constant darkness; DD2 - second day of constant darkness) for sampling. CT rather than ZT was used to designate subjective time of day in constant darkness. All manipulations of mice during "dark" conditions were performed under dim red light.

\section{RNA isolation, quantification, and quantitative real-time PCR}

Total RNA was extracted from whole retina using the RNeasy kit and protocol (Qiagen Inc., Valencia, CA, USA), and was quantified by fluorescence using the Quant-iT RNA Assay Kit (Invitrogen/Molecular Probes, Eugene, Oregon, USA). Reverse transcription was performed on total RNA (at least $250 \mathrm{ng}$ ) preparations using QuantiTect Reverse Transcription Kit (Qiagen Inc. Valencia, CA, USA) containing oligo-dTs and random primers, thus, enabling measurement of ribosomal RNA as well as mRNA. RT-PCR reactions were performed in $25 \mu \mathrm{L}$ total volume with $2 \mu \mathrm{L}$ cDNA, $1 \mathrm{X}$ QuantiFast Syber Green PCR Kit (Qiagen Inc., Valencia, CA, USA) and $300 \mathrm{nM}$ intron-spanning gene specific forward and reverse primers in a Bio-Rad iCycler (Bio-Rad, Hercules, CA, USA). The quantification of transcript level was performed by comparing the threshold cycle for amplification of the unknown to those of six concentrations of standard cDNAs for each respective transcript. Each sample was assayed in duplicate. Two RNAs were used for normalization, either hypoxanthine guanine phosphoribosyltransferase (Hprt) mRNA or 18S ribosomal RNA, with comparable results. Results are expressed relative to the lowest mean value in each experiment.

\section{Laser capture microdissection (LCM)}

Whole mouse eyes, frozen and embedded in OCT (Tissue-Tek, Torrance, CA, USA), were cut at $10 \mu \mathrm{m}$ thickness and mounted on polyethylene napthalate membrane glass slides (Applied Biosystems, Foster City, CA, USA). In a sterile environment, frozen sections were thawed for $30 \mathrm{~s}$ and fixed in $75 \%$ ethanol for $30 \mathrm{~s}$ followed by a wash in RNase-free water for $30 \mathrm{~s}$. The sections were stained with HistoGene (Applied Biosystems, Foster City, CA, USA) staining solutions for approximately $15 \mathrm{~s}$ followed by a wash with RNase-free water for $30 \mathrm{~s}$. The sections were dehydrated in graded ethanol solutions $(75 \%, 30 \mathrm{~s} ; 95 \%, 30 \mathrm{~s}$; $100 \%, 30 \mathrm{~s}$ ), cleared in xylene (>5 min), and air-dried for $5 \mathrm{~min}$.

LCM was performed to capture the outer nuclear layer and inner segments of photoreceptor cells onto HS-CapSure non-contact LCM films using ArcturusXT system (Applied Biosystems, Foster City, CA, USA). A low-energy ultraviolet laser was used to cut around the border of the desired tissue area, followed by low-energy infrared laser pulses were used to attach the tissue to LCM film. The outer nuclear layer and inner segments were lifted away from the tissue section, leaving all unwanted cells behind and providing a pure population for cell-specific molecular analysis. When dissecting the photoreceptor cell layer (inner segments and outer nuclear layer), the row of nuclei abutting the outer plexiform layer were untouched to avoid cross contamination with the inner retina. Additionally, outer segments were not captured, because mRNA levels are highest in the photoreceptor soma and inner segments, and to avoid contamination from the adjacent retinal pigment epithelium. The PicoPure RNA Isolation Kit (Applied Biosystems, Foster City, CA, USA) was used to purify total RNA from captured tissue. Total RNA was reverse transcribed using random primers and subjected to real-time PCR analysis as described above.

\section{In vivo agonist and antagonist experiments}

Mice, maintained in $L D$, were injected subcutaneously for 6 six days with a selective $D_{4} R$ antagonist, L-745,870 (Patel et al., 1997) at $1 \mathrm{mg} / \mathrm{kg}, 30 \mathrm{~min}$ before light onset (ZT 23.5). The drug and control were prepared in $0.3 \%$ carboxymethylcellulose (Sigma-Aldrich, St. Louis, MO, USA). Retinas were dissected during the subjective day and subjective night of 
DD1 following the 6th day of injections at CT 5, CT 10, CT 15, and CT 20. Since the rhythmic expression of $A d c y l$ has been extensively studied, we chose this truncated time scale to determine the effect of $\mathrm{D}_{4} \mathrm{R}$ antagonism on the peak of Adcyl retinal expression. RNA was isolated and assayed for Adcyl expression.

WT mice were injected intraperitoneally with PD 168,077 (1 mg/kg, Tocris, Ellisville, MO, USA), a selective $\mathrm{D}_{4} \mathrm{R}$ agonist, or vehicle 4 hrs before the onset of light (ZT 20) for 2 days during a 12 hour light/dark cycle. The injections were performed under dim red light. On the third day mice were kept in constant darkness to eliminate any light response. They were injected with PD 168,077 or vehicle 4 hrs before subjective light onset, and retinas were removed at ZT 21, CT 0, CT 4, and CT 8. Retinal RNA was isolated and assayed for Adcyl mRNA. An additional group of animals, on a $12 \mathrm{hr}$ LD cycle, were treated with a single injection of PD 168,077 administered at ZT 20, to investigate an acute effect of the drug on Adcyl mRNA expression. PD 168,077 was dissolved in dimethyl sulfoxide, and then diluted with sterile phosphate buffered saline to a final dimethyl sulfoxide concentration of approximately $1 \%$.

\section{Retinal cyclic AMP accumulation}

WT and $\mathrm{Drd}^{-1-}$ mice were kept in DD and dissected at various times of subjective day or subjective night (CT 2, 8, 14, 20). Retinas were placed in cold, oxygenated Earle's salt solution (115 mM NaCl, $3 \mathrm{mM} \mathrm{KCl}, 1.8 \mathrm{mM} \mathrm{CaCl}_{2}, 0.8 \mathrm{mM} \mathrm{MgSO}_{4}, 0.9 \mathrm{mM} \mathrm{NaH}_{2} \mathrm{PO}_{4}, 26$ $\mathrm{mM} \mathrm{NaHCO}_{3}, 5.5 \mathrm{mM}$ glucose) at $\mathrm{pH} 7.4$, equilibrated with $95 \% \mathrm{O}_{2} / 5 \% \mathrm{CO}_{2}$. Individual retinas where transferred to cell culture plates containing Earle's salt solution supplemented with $1 \mathrm{mM}$ 3-isobutyl-1-methylxanthine (Sigma, St. Louis, MO, USA). The retinas were incubated in darkness at $37^{\circ} \mathrm{C}$ in an atmosphere of $95 \% \mathrm{O}_{2} / 5 \% \mathrm{CO}_{2}$ for $15 \mathrm{~min}$ in a water bath. Retinas were immediately frozen on dry ice and stored at $-80^{\circ} \mathrm{C}$ until cyclic AMP levels were measured by radioimmunoassay (RIA, Perkin Elmer, Waltham, MA, USA).

\section{Adenylyl cyclase assay}

Retinas were dissected from WT and $\mathrm{Drd4} 4^{-/-}$mice during the day and night (ZT4 and ZT16, respectively), and were immediately frozen and stored at $-80^{\circ} \mathrm{C}$. Basal and $\mathrm{Ca}^{2+} /$ calmodulin-stimulated adenylyl cyclase activities were measured by assessing the conversion of $\left[\alpha^{32} \mathrm{P}\right]$ ATP to $\left[{ }^{32} \mathrm{P}\right]$ cyclic AMP by partially purified retinal membranes, as described previously (Jackson et al., 2009).

\section{Statistical analysis}

Analysis of multiple group data was performed using one-, two-, and three-way analysis of variance (ANOVA, SigmaStat) with Student-Newman-Keuls (SNK) multiple comparison test where applicable. Comparisons of two groups were made with two-tailed Student's ttest. Error bars represent standard error of the mean (SEM).

\section{Results}

\section{Daily rhythms of Drd4 transcript levels in mouse retina}

Diurnal (LD) and circadian rhythms (DD2) of $\operatorname{Drd} 4 \mathrm{mRNA}$ were evaluated by measuring the transcript level at $4 \mathrm{hr}$ intervals over a $24 \mathrm{hr}$ period. Drd4 mRNA levels fluctuated as daily rhythms in mice exposed to LD or DD2 (Fig. 1). In LD, transcript levels were high at the time of light onset, decreased dramatically by ZT4, and remained depressed until the lights went out (Fig. 1A; 2-way ANOVA, factor time $\mathrm{F}_{6,81}=24.486$, $\mathrm{P}<0.001$ ). In the dark phase of the LD cycle, Drd4 mRNA levels increased by ZT16 and remained elevated through the remainder of the night. During DD2, relative transcript levels were higher overall compared to those in LD (Fig. 1; 2-way ANOVA, factor - lighting condition LD vs. 
DD2, $\left.\mathrm{F}_{1,81}=157.86, \mathrm{P}<0.001\right)$. A notably dampened but significant rhythm persisted in the second day of constant darkness with a trough at CT 8 and a peak at CT 20 (Fig. 1B; SNK LD vs. DD2, $\left.\mathrm{q}_{2}=17.769, \mathrm{P}<0.001\right)$.

\section{Dopamine D4 receptors and circadian cyclic AMP synthesis in retina}

Cyclic AMP accumulation in mouse retina, measured in DD, occurred as a circadian rhythm with levels being lower during the subjective day and rising significantly during the early subjective night (Fig. 2; 2-way ANOVA, factor - time, $\mathrm{F}_{3,38}=9.163, \mathrm{P}<0.001$ ), peaking at $\sim$ CT 14. Interestingly, cyclic AMP accumulation in retinas of $\mathrm{Drd} 4^{-/-}$mice was significantly lower at all times of subjective day and subjective night and displayed no detectable rhythm (Fig. 2; factor - genotype $\mathrm{F}_{1,38}=108.64$, $\mathrm{P}<0.001$, genotype $\times$ time $\mathrm{F}_{3,38}$ $=11.657, \mathrm{P}<0.001)$. These data suggest that $\mathrm{D}_{4} \mathrm{R}$ expression is necessary to maintain normal cyclic AMP levels as well as the circadian rhythm of its synthesis.

Knowing that the circadian rhythm of cyclic AMP is influenced by $\mathrm{D}_{4} \mathrm{R}$, we examined daily expression pattern of Adcyl in wild type and $\operatorname{Drd4^{-/-}}$ mice. On DD2, Adcyl transcript levels in WT control retina displayed a significant rhythm with highest levels in the middle of the subjective day (Fig. 3; 2-way ANOVA, factor - genotype $\mathrm{F}_{1,40}=30.77$, $\mathrm{P}<0.001$; factor time $\mathrm{F}_{3,40}=5.225, \mathrm{P}=0.004$; genotype $\times$ time, $\mathrm{F}_{3,40}=4.979, \mathrm{P}=0.005$ ). In contrast, Adcyl expression in $\mathrm{Drd} 4^{-/-}$retinas showed no statistically significant rhythm and transcript levels in the knock out were significantly lower at CT $8\left(\mathrm{SNK}, \mathrm{q}_{2}=8.101, \mathrm{P}<0.001\right)$ and CT 20 $\left(\mathrm{q}_{2}=4.563, \mathrm{P}=0.003\right)$ compared to that in WT retinas (Fig. 3). To determine if these changes were occurring in photoreceptor cells, the photoreceptor layer was isolated from retinal frozen sections of WT and $\mathrm{Drd} 4^{-/-}$mice at mid-day and mid-night in LD and subjected to qRT-PCR. As shown in Figure 4, Adcyl transcript level was significantly higher at ZT 6 than at ZT 18 in photoreceptors of WT mice (2-way ANOVA, genotype $\mathrm{F}_{1,17}=6.169$, $\mathrm{P}=0.024$; time $\mathrm{F}_{1,17}=3.95, \mathrm{P}=0.063$; time $\times$ genotype, $\mathrm{F}_{1,17}=0.026$; SNK WT ZT 6 vs. $\left.\mathrm{ZT} 18, \mathrm{q}_{2}=4.517, \mathrm{P}=0.005\right)$. In contrast, no day-night difference of Adcyl mRNA was observed in photoreceptors of $\operatorname{Drd4^{-I}}$ mice $\left(\mathrm{q}_{2}=0.434, \mathrm{P}=0.763\right)$.

To further test the role of $\mathrm{D}_{4}$ Rs in rhythmic Adcyl expression, WT mice were treated for 6 days with the $\mathrm{D}_{4} \mathrm{R}$ antagonist, L745,870 (1 mg/kg, i.p.), administered at $\sim \mathrm{ZT} 23.5$, approximately $30 \mathrm{~min}$ prior to the time of light onset (ZT 0 ) of the daily light-dark cycle. The rationale for administering the drug at this time of day was to block the $\mathrm{D}_{4}$ Rs before the light-evoked increase of dopamine release upon light onset. When assessed in constant darkness (DD1) following the sixth day of drug treatment, a significant rhythm in Adcyl mRNA levels was observed in the vehicle-treated mice but not in those treated with L745,870 (Fig. 5; 2-way ANOVA, factor - time $\mathrm{F}_{3,34}=10.557, \mathrm{P}<0.001$; factor - treatment [vehicle vs. L745,870] $\mathrm{F}_{1,34}=41.195, \mathrm{P}<0.001$; genotype $\times$ treatment $\mathrm{F}_{3,34}=22.482$, $\mathrm{P}<0.001)$.

Adenylyl cyclase activity was assayed in retinal membranes to determine if there is a rhythm in $\mathrm{Ca}^{2+} / \mathrm{CaM}$-dependent enzyme activity in WT mouse retina and, if so, if the rhythm is disrupted in retinas of $\mathrm{Drd}^{-/-}$mice (Fig. 6). In WT samples, $\mathrm{Ca}^{2+} / \mathrm{CaM}$ increased adenylyl cyclase activity at both ZT 4 and ZT 16, but the increase at ZT 16 was significantly larger than that at ZT 4; no significant difference in basal activity was observed between the two time points (3-way ANOVA, time $\mathrm{F}_{1,40}=9.317, \mathrm{P}=0.004$; assay condition [basal vs. $\mathrm{Ca}^{2+}$ / $\mathrm{CaM}] \mathrm{F}_{1,40}=217.70, \mathrm{P}<0.001$; genotype $\mathrm{F}_{1,40}=326.39, \mathrm{P}<0.001$; time $\times$ genotype $\mathrm{F}_{1,40}=$ 17.239, $\mathrm{P}<0.001$; assay condition $\times$ genotype, $\mathrm{F}_{1,40}=126.34, \mathrm{P}<0.001$; time $\times$ assay condition $\times$ genotype, $\mathrm{F}_{1,40}=10.501, \mathrm{P}=0.002$ ). In retinal membranes from $\mathrm{Drd} 4^{-l-}$ mice, basal activity was lower than that in WT samples at both times of day, indicating an overall reduction of adenylyl cyclase. $\mathrm{Ca}^{2+} / \mathrm{CaM}$-stimulated activity was nearly abolished in 
$\operatorname{Drd} 4^{-1-}$ samples compared to WT controls. Moreover, there was no difference in basal or $\mathrm{Ca}^{2+} / \mathrm{CaM}$-stimulated activity between ZT 4 and ZT 16 in the $\operatorname{Drd}^{-/-}$samples.

Collectively these data indicate that the $\mathrm{D}_{4} \mathrm{R}$ and its activation plays a critical role in regulating the rhythmic expression of $\mathrm{AC} 1$ at the transcript and enzyme activity levels in the retina, thereby maintaining the circadian rhythm of cyclic AMP synthesis.

\section{Dopamine $\mathrm{D}_{\mathbf{4}}$ receptor activation mediates rhythmic behavior of Adcy1 expression}

Based on the results showing retinal Adcyl mRNA expression is rhythmic and controlled by the $D_{4} R$, we next hypothesized that activation of the $D_{4} R$ at an atypical time of day could change its normal expression pattern, thereby causing a phase shift in its rhythm. To test this hypothesis we injected mice with PD 168,077 , a selective $\mathrm{D}_{4} \mathrm{R}$ agonist, 4 hrs before the normal surge in dopamine release at light onset (ZT 0). WT mice were injected with drug or vehicle for 2 days under a normal light/dark cycle and on a $3^{\text {rd }}$ day in constant darkness. PD 168,077 treatment caused Adcyl mRNA levels to increase earlier in the day than in the vehicle treated controls (Fig. 7; 2-way ANOVA: treatment [vehicle vs. PD 168,077] $\mathrm{F}_{1,30}=$ 4.556, $\mathrm{P}=0.04$; time $\mathrm{F}_{3,30}=3.810, \mathrm{P}=0.02$; treatment $\times$ time $\mathrm{F}_{3,30}=3.296, \mathrm{P}=0.03$ ). Mice injected with PD 168,077 (1mg/kg) showed a steady increase in Adcyl levels at CT 0 and CT 4 - when compared to the ZT 21 time point. Conversely, the vehicle-treated animals did not show a significant increase in expression until the CT 8 time point, providing evidence that $\mathrm{D}_{4} \mathrm{R}$ activation in the late night can phase shift the $A d c y l$ rhythm. As a control for a possible direct stimulatory effect of $\mathrm{D}_{4} \mathrm{R}$ activation on Adcyl expression, mice were injected with a single dose of PD 168,077 $(1 \mathrm{mg} / \mathrm{kg})$ administered $4 \mathrm{~h}$ before subjective dawn, with Adcyl levels quantified $4 \mathrm{~h}$ later (CT 0). Under these conditions, PD 168,077 did not cause a significant increase in Adcyl gene expression (Adcyl mRNA/18S rRNA: Vehicle $=[18.9 \pm$ $1.3]^{*} 10^{-3} ;$ PD $168,077=[18.5 \pm 0.9] * 10^{-3} ; \mathrm{N}=6$ /group), indicating that the advance of the Adcyl mRNA expression pattern observed in Figure 6 is not due to acute induction of Adcyl by the $\mathrm{D}_{4} \mathrm{R}$.

\section{DISCUSSION}

Our results indicate that the $\mathrm{D}_{4} \mathrm{R}$ is critical for maintaining normal circadian expression of $\mathrm{AC} 1$ and cyclic AMP synthesis in mouse retina. Our major findings are as follows: AC1 mRNA and enzyme activity are rhythmically controlled by $\mathrm{D}_{4} \mathrm{R}$; the phase of Adcyl mRNA expression rhythm is shifted by activation of the $\mathrm{D}_{4} \mathrm{R}$ at night in darkness, when dopamine levels are low. Overall, the data suggest that $\mathrm{D}_{4} \mathrm{R}$ activation acts as an entrainment stimulus synchronizing activity rhythms of AC1, thereby modulating the circadian synthesis of cyclic AMP in the mouse retina.

The retina uses endogenous circadian oscillators to regulate retinal physiology under lightadapted conditions (Storch et al. 2007; Cameron et al., 2008). This allows for fine-tuning of the retinal signals across a large range of light intensities as a function of time-of-day. The mechanisms involved are not well understood and there are many different processes contributing to light- and dark-adaptation, including electrical coupling between photoreceptors and retinal neurons (Vardi \& Smith, 1996). Ribelayga et al. (2008) have shown that the retinal clock controls rod-cone coupling by a mechanism that involves dopamine. This study's focus was to define novel circadian signaling processes that may contribute to circadian regulation of retinal function through activation of the $\mathrm{D}_{4} \mathrm{R}$. Klitten et $a l$. (2008) demonstrated that $D r d 4$ mRNA shows rhythmic expression in rat retina and pineal gland, thus setting up a possible site for circadian regulation. This modulation may control the circadian fine-tuning of retinal signaling, perhaps through connexin phosphorylation at rod-cone gap junctions or other cyclic AMP-dependent metabolic and synaptic actions (Urschel et al., 2006; Michaelides et al., 2010). 


\section{$D_{4} R$ control of the rhythmic expression of Adcy1}

The classical circadian feedback loop, consisting of the core clock genes Bmall, Clock, Period1/2, and Cryptochrome1/2, has served as the defining standard for identifying cells or a population of cells with circadian oscillators (Ruan et al., 2006). In the retinal circadian research field there have been contrasting views concerning where the circadian pacemaker(s) are located. Using single-cell RT-PCR, Ruan et al., (2006) assayed mouse rod, horizontal, bipolar, amacrine and dopaminergic interplexiform cells for the presence of six core clock genes. All cell types, except rods, demonstrated expression of all six of the core clock genes. Also, this study demonstrates that $r d$ mice, whose photoreceptor layer endogenously degenerates, maintains robust circadian rhythms of Period2-driven luciferase activity in the inner retina, further suggesting oscillators required for rhythmic Period 2 expression in the inner nuclear layer are not contained within photoreceptor cells. However, these experiments do not address photoreceptor circadian phenomena, such as outer segment disc shedding (LaVail, 1976), rod-cone coupling (Ribelayga et al., 2008), $\mathrm{Na} / \mathrm{K}^{+}$ATPase activity (Shulman \& Fox, 1996), photoreceptor protein phosphorylation (Pozdeyev et al., 2008), and melatonin synthesis (Tosini and Menaker, 1996) that are observed in mammalian retina. Moreover, another study showed expression of the six core clock genes in the microdissected photoreceptor layer of the rat retina and demonstrated that rhythmic Period1driven luciferase and melatonin synthesis persists in isolated photoreceptor layers (Tosini $e t$ al., 2007). The $\mathrm{D}_{4} \mathrm{R}$ is the sole dopamine receptor subtype located on photoreceptor cells (Cohen et al., 1992) and has been shown to be involved in many of the aforementioned physiological functions (Witkovsky, 2004). Additionally, Klitten et al. (2008) demonstrated by in situ hybridization that the Drd4 transcript shows rhythmic expression only in photoreceptors of rat retina, although some hybridization was also observed in the inner retina. The common link between $\mathrm{D}_{4} \mathrm{R}$ and rhythmic physiological functions suggests a possible site for circadian regulation in photoreceptor cells.

Storch et al. (2007) demonstrated that Drd4 expression in mouse eye was rhythmic in LD even when the core clock mechanism was disrupted by elimination of Bmall. This observation suggested that the rhythm of Drd4 mRNA was light-driven and not regulated directly by circadian clocks. However, our results indicate that $\operatorname{Drd} 4 \mathrm{mRNA}$ expression in mouse retina is circadian, being rhythmic in both LD and DD, although the amplitude of the rhythm was reduced in constant darkness compared to that in cyclic light. These findings indicate that rhythmic $\mathrm{Drd} 4$ expression is regulated by both light and retinal circadian oscillators. Previous studies have shown that dopamine metabolism in retinas of wild type C57Bl/6 mice is light driven and not circadian (Doyle et al., 2002b; Pozdeyev et al., 2008). The larger amplitude of the Drd4 transcript rhythm observed in LD compared to DD was due to lower relative expression levels in light phase of the LD cycle when dopamine is released, suggesting that endogenous dopamine may down regulate $\mathrm{Drd} 4$ expression.

Our lab has recently reported that $A d c y l$ expression is modulated by $\mathrm{D}_{4} \mathrm{R}$ activation (Jackson et al., 2009). Currently, we show that the rhythm in Adcyl is damped or undetectable in $\mathrm{Drd4}^{-/}$mice or in mice treated for six days with a $\mathrm{D}_{4} \mathrm{R}$ antagonist. These findings provide strong evidence that the $\mathrm{D}_{4} \mathrm{R}$ plays a critical role in regulating the circadian expression of Adcyl. Currently, the mechanism for how $\mathrm{D}_{4} \mathrm{R}$ activation controls Adcyl mRNA expression is not known; however, there are studies that show $\mathrm{D}_{4} \mathrm{R}$ activation not only affects cAMP levels, but also activates the MAPK signaling pathways (Oldenhof et al., 1998; Oak et al., 2001).

\section{$D_{4} R$ control of rhythmic adenylyl cyclase enzyme activity}

The $\mathrm{D}_{4} \mathrm{R}$ regulates cyclic AMP production in retina primarily by controlling the activity of the type 1 adenylyl cyclase at the protein level (Jackson et al., 2009). Three adenylyl cyclase 
isozymes are known to interact with $\mathrm{Ca}^{2+}$ and $\mathrm{CaM}$ : $\mathrm{AC} 1, \mathrm{AC} 3$, and $\mathrm{AC} 8$ (Patel et al., 2001), with AC1 being primarily responsible for cyclic AMP accumulation in dark-adapted mouse photoreceptors (Jackson et al., 2009). While it was previously reported that Adcyl mRNA is expressed in a circadian rhythm in mouse retina (Storch et al., 2007), it was unknown if this resulted in daily changes in adenylyl cyclase activity. In the current study we demonstrated rhythmic activity of $\mathrm{Ca}^{2+} / \mathrm{CaM}$-stimulated adenylyl cyclase in retinal membranes from wild type mice with higher activity at night (Fig. 6). In contrast, $\mathrm{Ca}^{2+}$ / CaM-stimulated enzyme activity was greatly reduced and arrhythmic in retinal membranes of $\operatorname{Drd4^{-1-}}$ mice. These results suggest that there is less $\mathrm{AC} 1$ available for stimulation by $\mathrm{Ca}^{2+} / \mathrm{CaM}$ activity and that the amount of $\mathrm{AC} 1$ protein does not fluctuate rhythmically in $\operatorname{Drd} 4^{-/}$retina, which is consistent with the reduced levels and damped rhythms of Adcyl in $\operatorname{Drd} 4^{-/-}$retinas. However, we cannot exclude the possibility that post-translational modifications contribute to these differences. We conclude that the rhythmic changes seen in enzyme activity are directly related to the dopamine/ $\mathrm{D}_{4} \mathrm{R}$ signaling system in mammalian retina.

\section{Dopamine $/ D_{4} R$ signaling system controls cyclic AMP in mouse retina}

Cyclic AMP is a key second messenger that translates external cues into intracellular responses (Sands \& Palmer, 2008). One way to regulate cyclic AMP is through the $\mathrm{D}_{4} \mathrm{R}$ signaling pathway, which is negatively coupled to AC1 in retina (Jackson et al., 2009). Therefore, disrupting this receptor's function should lead to abnormalities in cyclic AMP regulation, as seen by Nir et al. (2002) and Jackson et al. (2009). In chick and rat, retinal rhythms of cyclic AMP are observed (Ivanova \& Iuvone, 2003; Fukuhara et al., 2004); to date this had not been established in mouse retina. The present results definitively show that cyclic AMP accumulation is circadian in retinas of WT mice. However, cyclic AMP levels in $\operatorname{Drd4^{-/-}}$ retinas are constitutively low and display no circadian rhythm. This result is striking because other dopamine receptors beside the $\mathrm{D}_{4} \mathrm{R}$, most notably the $\mathrm{D} 1$ receptor, regulate cyclic AMP accumulation in retina (Witkovsky, 2004). In contrast to the $\mathrm{D}_{4} \mathrm{R}$, dopamine D1 receptors activate adenylyl cyclase. Thus, it may seem surprising that removal of the $\mathrm{D}_{4} \mathrm{R}$ did not reveal a D1-receptor mediated increase of cyclic AMP accumulation. Deletion of the $\mathrm{D}_{4} \mathrm{R}$ does not affect the expression of $\operatorname{Drdl}$ (Jackson et al., 2009), the gene that encodes the D1 receptor. Light stimulates cyclic AMP accumulation in the $\operatorname{Drd} 4^{-1}$ retina except under conditions where synaptic transmission from photoreceptors to inner retinal neurons is blocked by exogenous glutamate (Nir et al., 2002). This stimulatory effect of light is eliminated by blocking D1 receptors (Nir et al., 2002). The constitutively low levels of cyclic AMP in the current study can be attributed to the reduced and constitutive expression of Adcyl in the $\operatorname{Drd4^{-l-}}$ retina and to the experiment having been conducted in constant darkness. These observations have several important implications. They support the generally held view that D1 receptors are expressed only in the inner retina. They suggest that $\mathrm{D} 1$ receptors may couple to adenylyl cyclase isoforms other than $\mathrm{AC} 1$, since $A d c y l$ and $\mathrm{Ca}^{2+} / \mathrm{CaM}$-stimulated adenylyl cyclase are dramatically reduced in retinas of $\operatorname{Drd}^{-1-}$ mice (Jackson et al., 2009; present results). The observations also suggest that the circadian rhythm of retinal cyclic AMP accumulation may derive primarily from photoreceptors, although additional experimentation is needed to conclusively establish this point. Lastly, these data indicate that the circadian nature of cyclic AMP synthesis in mammalian retina is controlled primarily by the dopamine $/ \mathrm{D}_{4} \mathrm{R}$ signaling system.

\section{Is the dopamine/ $D_{4} R$ signaling system an entrainment mechanism in retina?}

The current study shows that $A d c y l$ expression rhythms are damped or lost in the absence of $\mathrm{D}_{4} \mathrm{R}$ signaling. Conceivably, Adcyl expression rhythms could be driven by dopamine. Alternatively, dopamine released in the morning at light onset may serve to entrain or resynchronize circadian clocks in mouse retina that control Adcyl rhythms. The experiments 
in this study were performed with mice on a C57B1/6 background, which show light-driven but not circadian control of dopamine metabolism (Doyle et al., 2002a; Pozdeyev et al., 2008). This suggests that dopamine does not drive the Adcyl rhythm, since the transcript rhythm persists in constant darkness but dopamine rhythms do not. This conclusion is further supported by our observation that acute administration of a $\mathrm{D}_{4} \mathrm{R}$ agonist did not induce $A d c y 1$ mRNA expression. In contrast, injections of the $\mathrm{D}_{4} \mathrm{R}$ agonist 4 hours prior to subjective dawn for three days caused Adcyl mRNA levels to increase earlier in the day compared to vehicle injected controls, supporting the hypothesis that dopamine entrains the rhythm of Adcyl expression. In Xenopus retina, quinpirole, a $\mathrm{D}_{2} / \mathrm{D}_{4}$ dopamine receptor agonist, can phase shift the circadian rhythm of melatonin release from photoreceptors (Cahill \& Besharse, 1991a). Similarly, dopamine synchronizes multiple circadian oscillators regulating rhodopsin promoter activity in zebrafish photoreceptors (Yu et al., 2007).

Another possible explanation for the apparent phase shift of the Adcyl transcript rhythm following three days of PD 168,077 administration is that the agonist may have changed the pattern of $D_{4} R$ availability at the plasma membrane. If repeated treatment with the agonist resulted in up-regulation of the receptor late in the evening, there might be a direct stimulatory effect of $\mathrm{D}_{4} \mathrm{R}$ activation that could have been missed following a single injection of PD 168,077. This mechanism, however, seems unlikely since agonist treatment usually down-regulates receptors (Duman and Nestler, 1995). In addition, the half-life of PD 168,077 in the rat central nervous system is relatively short ( 1 hr; Moreland et al., 2005) and changes in receptor up- or down-regulation usually occur in response to tonic receptor occupancy (Duman and Nestler, 1995).

In apparent contradiction to our results, Ruan et al. (2008) found that tonic exposure to a dopamine D1 receptor agonist, but not a D2/D4 agonist, altered the phase of Per2::Luc rhythms in isolated mouse retina. However, the Per2::Luc signal emanates primarily from the inner retina and persists in retinas lacking photoreceptors (Ruan et al., 2006). In contrast, our data show that the $\mathrm{D}_{4} \mathrm{R}$ affects the Adcyl rhythm in photoreceptors. Coupled with the observation of reduced amplitude of the Per 1 mRNA rhythms throughout the retinae of Drd2 null mice (Yujnovsky et al., 2006), these observations illustrate a major role for dopamine, acting through multiple receptor subtypes, in the circadian organization of the mammalian retina.

In conclusion, the dopamine/ $\mathrm{D}_{4} \mathrm{R}$ signaling system plays an important role in retinal circadian regulation, particularly in photoreceptors. The rhythm in $\mathrm{D}_{4} \mathrm{R}$ may control subordinate rhythms that are driven by its timely activation by dopamine, thereby, controlling the phase of rhythmic gene expression (Adcyl), adenylyl cyclase enzyme activity, and cyclic AMP production. Our results, in conjunction with studies performed on cold-blooded vertebrates, support the hypothesis that dopamine, acting through $\mathrm{D}_{2}$-like $\left(\mathrm{D}_{2}\right.$ or $\mathrm{D}_{4}$ ) receptors, serves as an entrainment stimulus to synchronize circadian clocks regulating retinal gene expression and function.

\section{Acknowledgments}

The authors gratefully acknowledge Dr. Tonya Taylor, Amy Visser, and Jane Abey for technical assistance, Dr. Rashidul Haque for helpful suggestions throughout the course of this investigation, and David Grandy and Malcolm Lowe for providing breeders of the $\mathrm{Drd} 4^{-/-}$mice. This study was supported by grants from the NIH (R01 EY004864, P30 EY006360, T32 EY007092, F31 EY21089), and an unrestricted departmental grant from Research to Prevent Blindness (RPB). PMI is a recipient of the Senior Scientific Investigator Award from RPB. 


\section{Abbreviations}

\begin{tabular}{|c|c|}
\hline $\mathbf{A C}$ & Adenylyl Cyclase \\
\hline Adcy1 & Gene encoding the type 1 adenylyl cyclase \\
\hline ANOVA & Analysis of Variance \\
\hline CaM & Calmodulin \\
\hline CT & Circadian Time \\
\hline $\mathbf{D}_{\mathbf{4}} \mathbf{R}$ & Dopamine $\mathrm{D}_{4}$ Receptor \\
\hline DD & Constant Darkness \\
\hline Drd4 & Gene encoding the dopamine $\mathrm{D}_{4}$ receptor \\
\hline $\operatorname{Drd4} 4^{-1-}$ & Mice lacking the dopamine $\mathrm{D}_{4}$ receptor \\
\hline Hprt & Gene encoding hypoxanthine guanine phosphoribosyltransferase \\
\hline LD & Light/Dark \\
\hline SEM & Standard Error of the Mean \\
\hline SNK & Student-Newmann-Keuls test \\
\hline WT & Wild-type \\
\hline ZT & Zeitgeber Time \\
\hline
\end{tabular}

\section{References}

Bai L, Zimmer S, Rickes O, Rohleder N, Holthues H, Engel L, Leube R, Spessert R. Daily oscillation of gene expression in the retina is phase-advanced with respect to the pineal gland. Brain Res. 2008; 1203:89-96. [PubMed: 18321474]

Baldridge WH, Vaney DI, Weiler R. The modulation of intercellular coupling in the retina. Semin Cell Dev Biol. 1998; 9:311-318. [PubMed: 9665867]

Cahill GM, Besharse JC. Resetting the circadian clock in cultured Xenopus eyecups: regulation of retinal melatonin rhythms by light and D2 dopamine receptors. J Neurosci. 1991a; 11:2959-2971. [PubMed: 1682423]

Cahill GM, Grace MS, Besharse JC. Rhythmic regulation of retinal melatonin: metabolic pathways, neurochemical mechanisms, and the ocular circadian clock. Cell Mol Neurobiol. 1991b; 11:529_ 560. [PubMed: 1742771]

Cameron MA, Pozdeyev N, Vugler AA, Cooper H, Iuvone PM, Lucas RJ. Light regulation of retinal dopamine that is independent of melanopsin phototransduction. Eur J Neurosci. 2009; 29:761-767. [PubMed: 19200071]

Chaurasia SS, Haque R, Pozdeyev N, Jackson CR, Iuvone PM. Temporal coupling of cyclic AMP and $\mathrm{Ca} /$ calmodulin-stimulated adenylyl cyclase to the circadian clock in chick retinal photoreceptor cells. J Neurochem. 2006; 99:1142-1150. [PubMed: 16981891]

Cohen AI, Blazynski C. Dopamine and its agonists reduce a light-sensitive pool of cyclic AMP in mouse photoreceptors. Vis Neurosci. 1990; 4:43-52. [PubMed: 1702315]

Cohen AI, Todd RD, Harmon S, O’Malley KL. Photoreceptors of mouse retinas possess D4 receptors coupled to adenylate cyclase. Proc Natl Acad Sci U S A. 1992; 89:12093-12097. [PubMed: 1334557]

Dorenbos R, Contini M, Hirasawa H, Gustincich S, Raviola E. Expression of circadian clock genes in retinal dopaminergic cells. Vis Neurosci. 2007; 24:573-580. [PubMed: 17705893]

Doyle SE, Grace MS, McIvor W, Menaker M. Circadian rhythms of dopamine in mouse retina: the role of melatonin. Vis Neurosci. 2002a; 19:593-601. [PubMed: 12507326] 
Doyle SE, McIvor WE, Menaker M. Circadian rhythmicity in dopamine content of mammalian retina: role of the photoreceptors. J Neurochem. 2002b; 83:211-219. [PubMed: 12358745]

Duman, RS.; Nestler, EJ. Signal transduction pathways for catecholamine receptors. In: Bloom, FE.; Kupfer, DJ., editors. Psychopharmacology: The fourth generation of progress. Raven Press; New York: 1995. p. 303-320.

Eskin A. Increasing external $\mathrm{K}+$ blocks phase shifts in a circadian rhythm produced by serotonin or 8benzylthio-cAMP. J Neurobiol. 1982; 13:241-249. [PubMed: 6281380]

Fukuhara C, Liu C, Ivanova TN, Chan GC, Storm DR, Iuvone PM, Tosini G. Gating of the cAMP signaling cascade and melatonin synthesis by the circadian clock in mammalian retina. J Neurosci. 2004; 24:1803-1811. [PubMed: 14985420]

Gustincich S, Contini M, Gariboldi M, Puopolo M, Kadota K, Bono H, LeMieux J, Walsh P, Carninci P, Hayashizaki Y, Okazaki Y, Raviola E. Gene discovery in genetically labeled single dopaminergic neurons of the retina. Proc Natl Acad Sci U S A. 2004; 101:5069-5074. [PubMed: 15047890]

Ivanova TN, Iuvone PM. Circadian rhythm and photic control of cAMP level in chick retinal cell cultures: a mechanism for coupling the circadian oscillator to the melatonin-synthesizing enzyme, arylalkylamine N-acetyltransferase, in photoreceptor cells. Brain Res. 2003; 991:96-103. [PubMed: 14575881]

Jackson CR, Chaurasia SS, Zhou H, Haque R, Storm DR, Iuvone PM. Essential roles of dopamine D4 receptors and the type 1 adenylyl cyclase in photic control of cyclic AMP in photoreceptor cells. J Neurochem. 2009; 109:148-157. [PubMed: 19166506]

Klitten LL, Rath MF, Coon SL, Kim JS, Klein DC, Moller M. Localization and regulation of dopamine receptor D4 expression in the adult and developing rat retina. Exp Eye Res. 2008; 87:471-477. [PubMed: 18778704]

LaVail MM. Rod outer segment disk shedding in rat retina: relationship to cyclic lighting. Science. 1976; 194:1071-1074. [PubMed: 982063]

Michaelides M, Pascau J, Gispert JD, Delis F, Grandy DK, Wang GJ, Desco M, Rubinstein M, Volkow ND, Thanos PK. Dopamine D4 receptors modulate brain metabolic activity in the prefrontal cortex and cerebellum at rest and in response to methylphenidate. Eur J Neurosci. 2010; 32:668-676. [PubMed: 20646063]

Moreland RB, Patel M, Hsieh GC, Wetter JM, Marsh K, Brioni JD. A-412997 is a selective dopamine D4 receptor agonist in rats. Pharmacol Biochem Behav. 2005; 82:140-147. [PubMed: 16153699]

Nir I, Haque R, Iuvone PM. Diurnal metabolism of dopamine in dystrophic retinas of homozygous and heterozygous retinal degeneration slow (rds) mice. Brain Res. 2000; 884:13-22. [PubMed: 11082482]

Nir I, Harrison JM, Haque R, Low MJ, Grandy DK, Rubinstein M, Iuvone PM. Dysfunctional lightevoked regulation of cAMP in photoreceptors and abnormal retinal adaptation in mice lacking dopamine D4 receptors. J Neurosci. 2002; 22:2063-2073. [PubMed: 11896146]

Oak JN, Lavine N, Van Tol HH. Dopamine D(4) and D(2L) Receptor Stimulation of the MitogenActivated Protein Kinase Pathway Is Dependent on trans-Activation of the Platelet-Derived Growth Factor Receptor. Mol Pharmacol. 2001; 60:92-103. [PubMed: 11408604]

Oldenhof J, Vickery R, Anafi M, Oak J, Ray A, Schoots O, Pawson T, von Zastrow M, Van Tol HH. SH3 binding domains in the dopamine D4 receptor. Biochemistry. 1998; 37:15726-15736. [PubMed: 9843378]

Patel S, Freedman S, Chapman KL, Emms F, Fletcher AE, Knowles M, Marwood R, McAllister G, Myers J, Curtis N, Kulagowski JJ, Leeson PD, Ridgill M, Graham M, Matheson S, Rathbone D, Watt AP, Bristow LJ, Rupniak NM, Baskin E, Lynch JJ, Ragan CI. Biological profile of L-745,870, a selective antagonist with high affinity for the dopamine D4 receptor. J Pharmacol Exp Ther. 1997; 283:636-647. [PubMed: 9353380]

Patel TB, Du Z, Pierre S, Cartin L, Scholich K. Molecular biological approaches to unravel adenylyl cyclase signaling and function. Gene. 2001; 269:13-25. [PubMed: 11376933]

Pozdeyev N, Tosini G, Li L, Ali F, Rozov S, Lee RH, Iuvone PM. Dopamine modulates diurnal and circadian rhythms of protein phosphorylation in photoreceptor cells of mouse retina. Eur J Neurosci. 2008; 27:2691-2700. [PubMed: 18547251] 
Prosser RA, Gillette MU. The mammalian circadian clock in the suprachiasmatic nuclei is reset in vitro by cAMP. J Neurosci. 1989; 9:1073-1081. [PubMed: 2538580]

Ribelayga C, Cao Y, Mangel SC. The circadian clock in the retina controls rod-cone coupling. Neuron. 2008; 59:790-801. [PubMed: 18786362]

Ruan GX, Allen GC, Yamazaki S, McMahon DG. An autonomous circadian clock in the inner mouse retina regulated by dopamine and GABA. PLoS Biol. 2008; 6:e249. [PubMed: 18959477]

Ruan GX, Zhang DQ, Zhou T, Yamazaki S, McMahon DG. Circadian organization of the mammalian retina. Proc Natl Acad Sci U S A. 2006; 103:9703-9708. [PubMed: 16766660]

Rubinstein M, Phillips TJ, Bunzow JR, Falzone TL, Dziewczapolski G, Zhang G, Fang Y, Larson JL, McDougall JA, Chester JA, Saez C, Pugsley TA, Gershanik O, Low MJ, Grandy DK. Mice lacking dopamine D4 receptors are supersensitive to ethanol, cocaine, and methamphetamine. Cell. 1997; 90:991-1001. [PubMed: 9323127]

Sands WA, Palmer TM. Regulating gene transcription in response to cyclic AMP elevation. Cell Signal. 2008; 20:460-466. [PubMed: 17993258]

Shulman LM, Fox DA. Dopamine inhibits mammalian photoreceptor $\mathrm{Na}+\mathrm{K}+$-ATPase activity via a selective effect on the alpha3 isozyme. Proc Natl Acad Sci U S A. 1996; 93:8034-8039. [PubMed: 8755598]

Steenhard BM, Besharse JC. Phase shifting the retinal circadian clock: xPer2 mRNA induction by light and dopamine. J Neurosci. 2000; 20:8572-8577. [PubMed: 11102460]

Storch KF, Paz C, Signorovitch J, Raviola E, Pawlyk B, Li T, Weitz CJ. Intrinsic circadian clock of the mammalian retina: importance for retinal processing of visual information. Cell. 2007; 130:730-741. [PubMed: 17719549]

Tosini G, Menaker M. Circadian rhythms in cultured mammalian retina. Science. 1996; 272:419-421. [PubMed: 8602533]

Tosini G, Davidson AJ, Fukuhara C, Kasamatsu M, Castanon-Cervantes O. Localization of a circadian clock in mammalian photoreceptors. FASEB J. 2007; 21:3866-3871. [PubMed: 17621597]

Tosini G, Pozdeyev N, Sakamoto K, Iuvone PM. The circadian clock system in the mammalian retina. BioEssays. 2008; 30:624-633. [PubMed: 18536031]

Urschel S, Hoher T, Schubert T, Alev C, Sohl G, Worsdorfer P, Asahara T, Dermietzel R, Weiler R, Willecke K. Protein kinase A-mediated phosphorylation of connexin36 in mouse retina results in decreased gap junctional communication between AII amacrine cells. J Biol Chem. 2006; 281:33163-33171. [PubMed: 16956882]

Vardi N, Smith RG. The AII amacrine network: coupling can increase correlated activity. Vision Res. 1996; 36:3743-3757. [PubMed: 8994576]

Witkovsky P. Dopamine and retinal function. Doc Ophthalmol. 2004; 108:17-40. [PubMed: 15104164]

Yu CJ, Gao Y, Li P, Li L. Synchronizing multiphasic circadian rhythms of rhodopsin promoter expression in rod photoreceptor cells. J Exp Biol. 2007; 210:676-684. [PubMed: 17267653]

Yujnovsky I, Hirayama J, Doi M, Borrelli E, Sassone-Corsi P. Signaling mediated by the dopamine D2 receptor potentiates circadian regulation by CLOCK:BMAL1. Proc Natl Acad Sci U S A. 2006; 103:6386-6391. [PubMed: 16606840] 


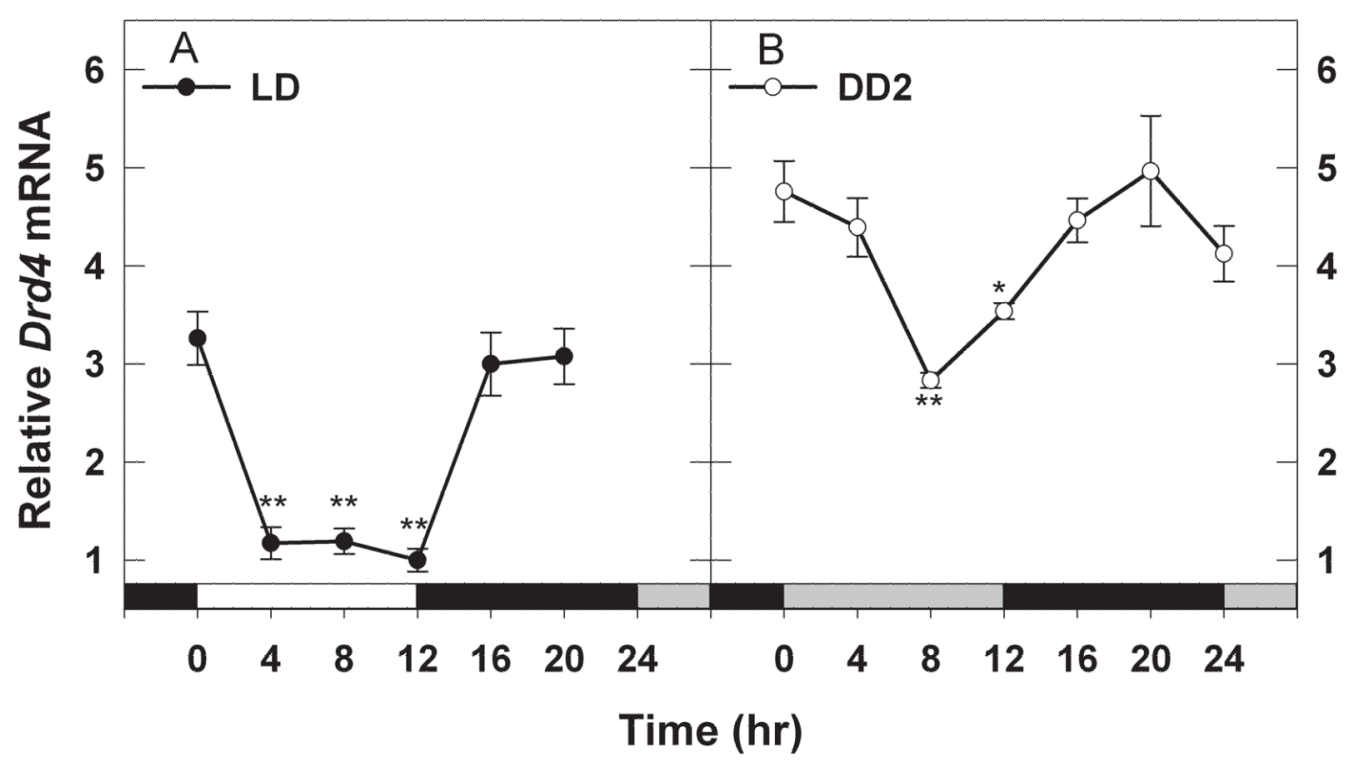

Fig. 1.

Diurnal and circadian rhythms of Drd4 mRNA expression in mouse retina. Drd4 mRNA levels were determined by real-time RT-PCR as described in Materials and methods under light/dark (LD; panel A) and constant dark (DD2; panel B) conditions. Drd4 transcript levels show significant rhythms $(* \mathrm{P} \leq 0.01 v s$ Time 0 ; $* * \mathrm{P}<0.001 v s$ Time 0$)$. In DD2 the $\operatorname{Drd} 4$ mRNA levels were significantly higher than in LD ( $\mathrm{P}<0.001$, LD vs DD2) and the rhythm had a lower amplitude. Data expressed as means \pm SEM, $n=5-7$ mice per group. White bars on the $\mathrm{X}$-axis represent daytime in light; gray bars represent subjective daytime in constant darkness; black bars represent night or subjective night in darkness. 


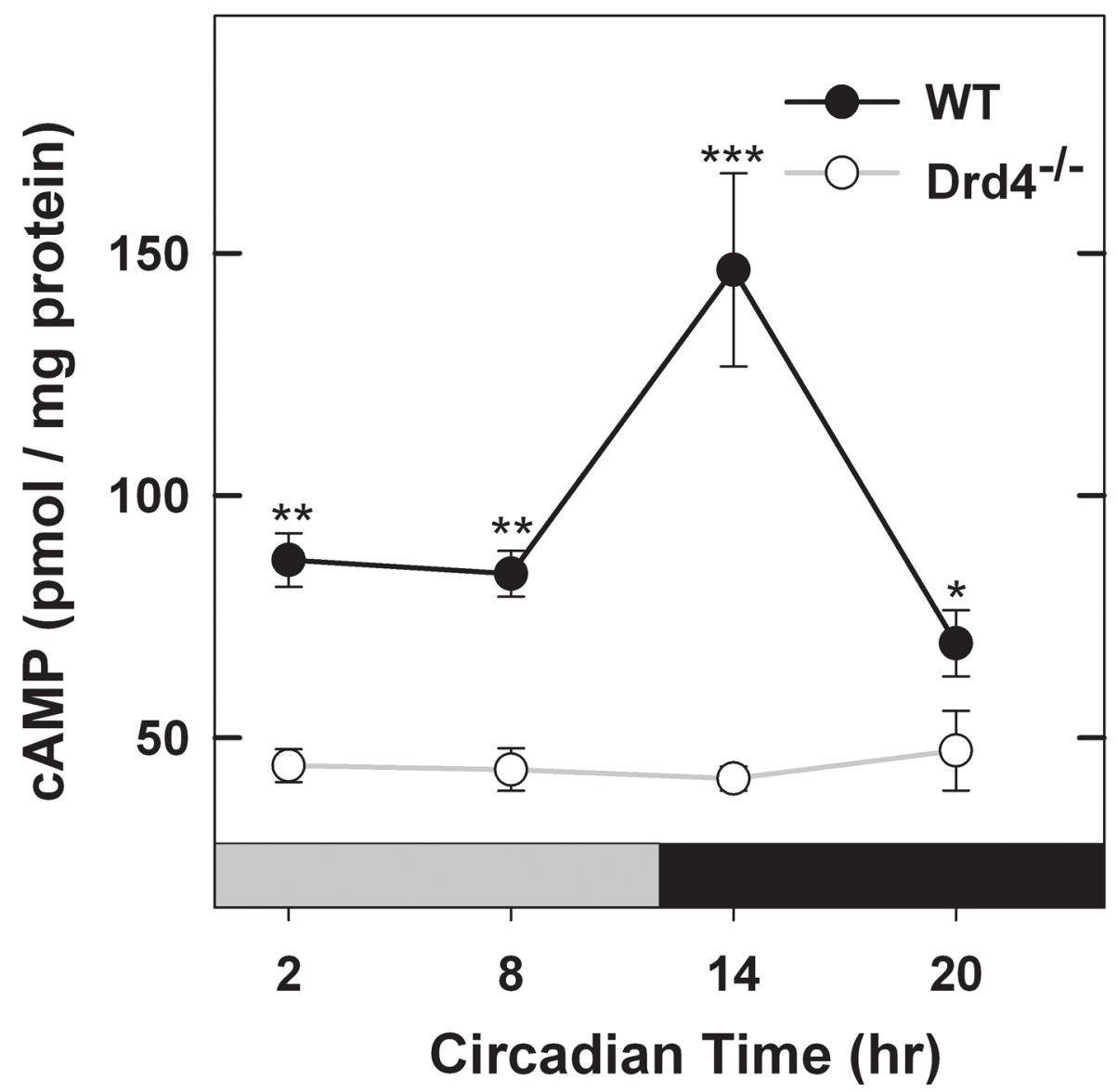

Fig. 2.

Cyclic AMP accumulation is circadian in retina of WT mice $(\mathrm{P}<0.001)$ but not in retina of Drd4 ${ }^{-1-}$ mice. Cyclic AMP accumulation was measured in constant darkness (DD) as described in Materials and methods. *** $\mathrm{P}<0.001 \mathrm{vs}$ all other groups in WT and Drd4 ${ }^{-1-}$ mice; WT $v s$ Drd4 ${ }^{-1-}$ at the same time-of-day, $* * \mathrm{P}<0.001$ at CT 2 and $8, * \mathrm{P}<0.05$ at CT20. Data expressed as means \pm SEM, $n=4-6$ per group. 


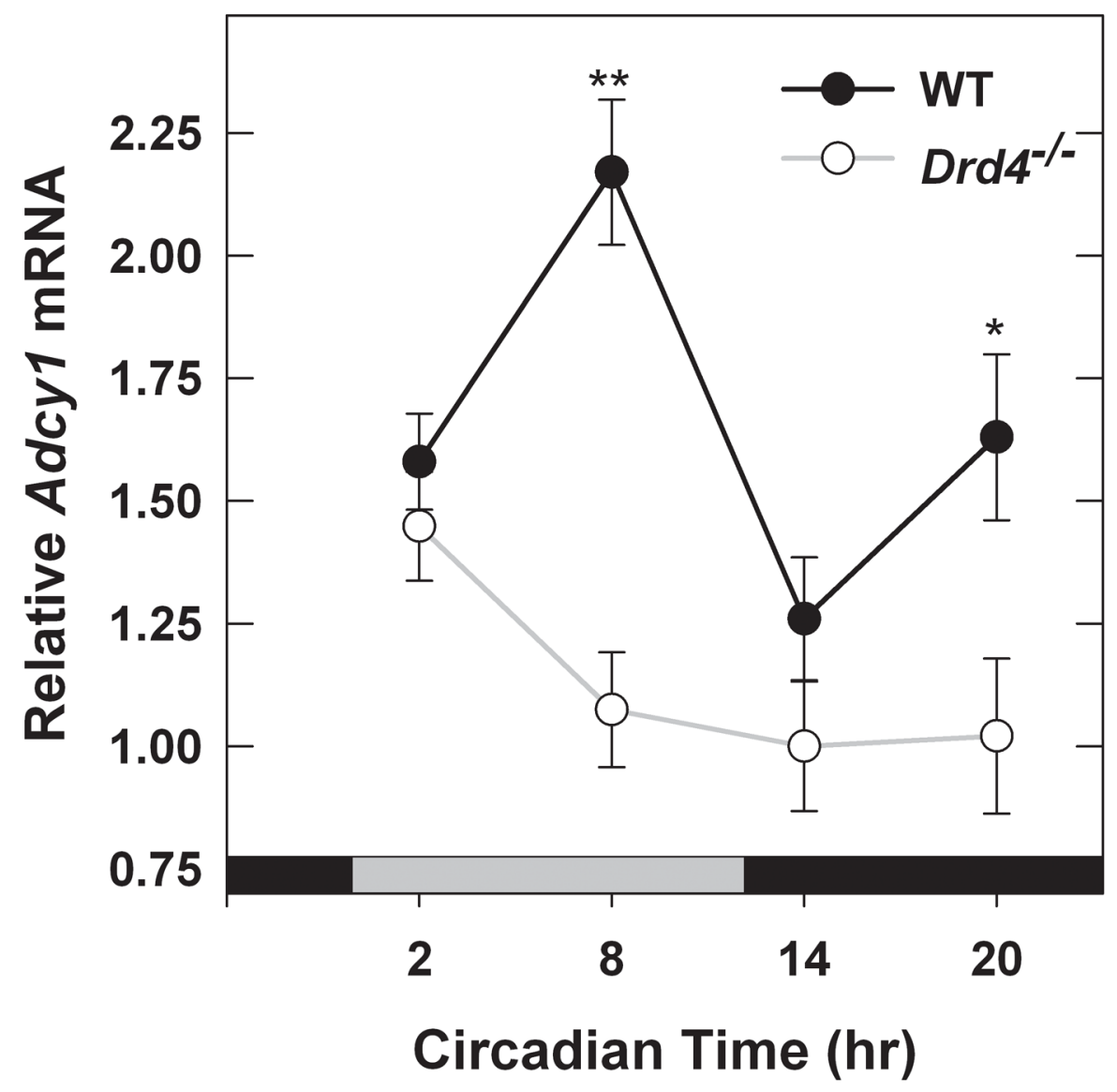

Fig. 3.

Comparison of rhythmic expression of Adcyl mRNA in $\mathrm{Prd}^{-/-}$retinas compared to WT controls. Adcyl mRNA levels in retinas dissected on DD2 were determined by real-time RTPCR as described in Materials and methods. Closed circles represent WT samples exhibiting a daily rhythm $(\mathrm{p}<0.001)$; open circles represent $\operatorname{Drd} 4^{-1-}$ samples, which show no detectable rhythm. *P=0.003, ** $<<0.001$ vs $\mathrm{Drd}^{-/-}$at the same time of day. Data expressed as mean \pm SEM, $\mathrm{n}=6$ per group. 


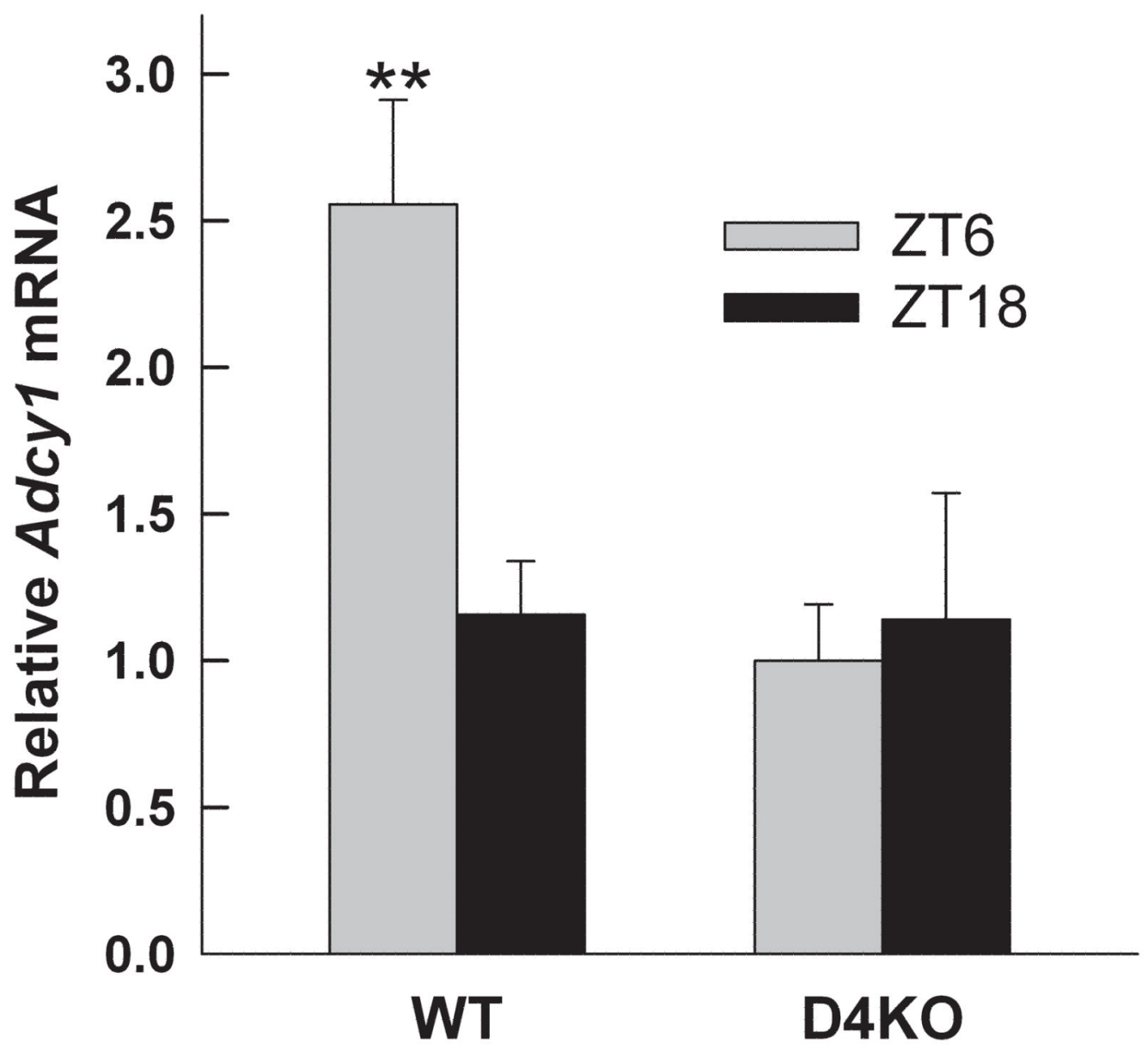

Fig. 4.

The day-night rhythm of Adcyl transcript expression in photoreceptor cells is absent in $\operatorname{Drd} 4^{-l-}$ mice. Eyes were dissected from WT and $\operatorname{Drd4^{-I-}}$ mice at mid-day and mid-night in LD. The photoreceptor layer of was isolated by LCM as described in Materials and methods and subjected to qRT-PCR analysis. ${ }^{*} \mathrm{P}=0.005$ vs. WT ZT18. Data are expressed as mean \pm SEM, $\mathrm{n}=5-6$ per condition. 


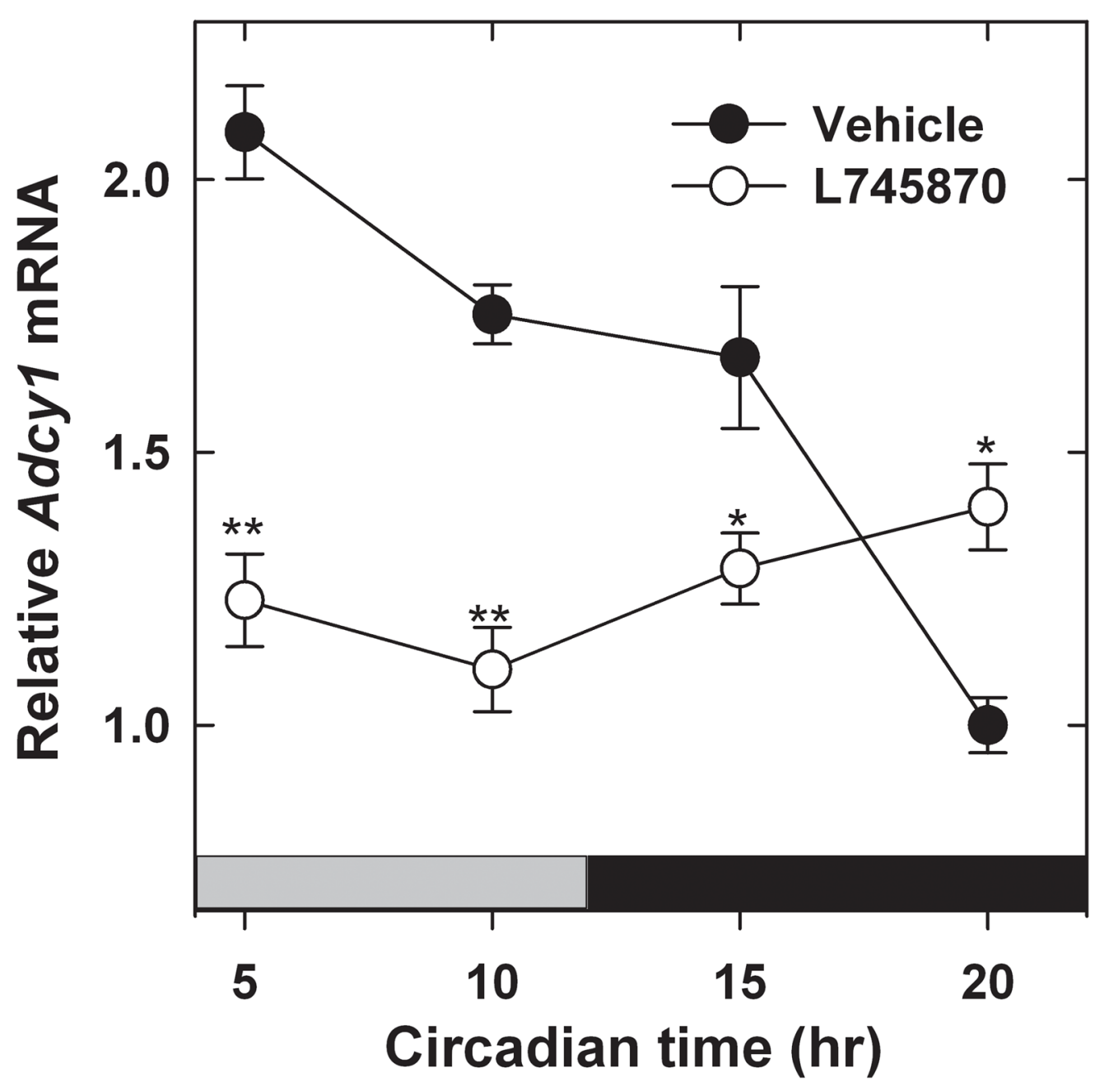

Fig. 5.

Effect of treatment with the $\mathrm{D}_{4} \mathrm{R}$ antagonist, L-745,870, on the Adcyl transcript rhythm. Mice, maintained in LD, were injected at ZT 23.5 for six days with $1 \mathrm{mg} / \mathrm{kg} \mathrm{L-745,870} \mathrm{or}$ vehicle as described in Materials and methods. After the last injection, retinas were dissected during the following subjective day or subjective night in DD1 at the times indicated in the figure. Mice injected with vehicle showed a statistically significant rhythm in Adcyl mRNA levels $(\mathrm{P}<0.001)$, while those injected with $\mathrm{L}-745,870$ did not. $* \mathrm{P}<0.01, * * \mathrm{P}<0.001$ vs Vehicle at the same time of day. 


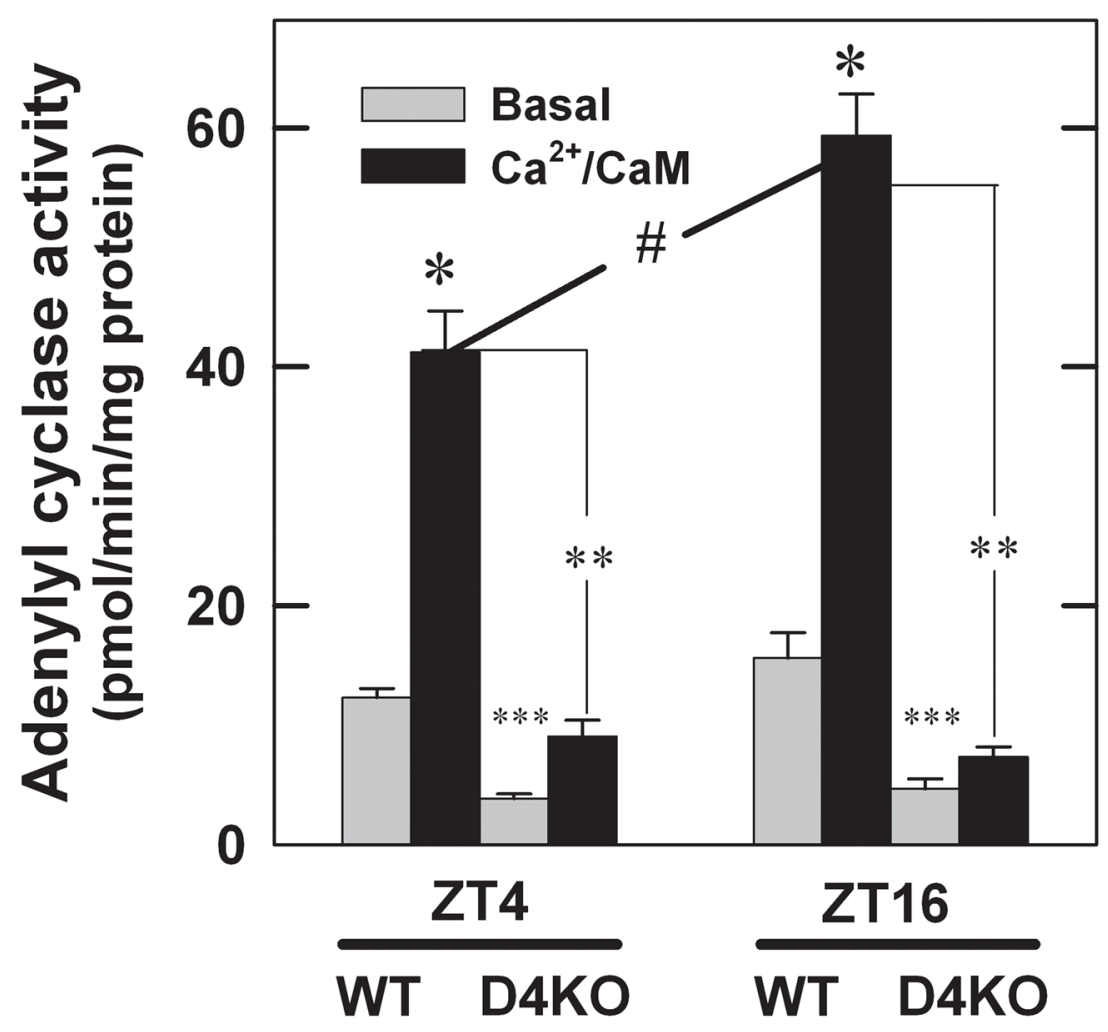

Fig. 6.

Adenylyl cyclase activity in $\mathrm{Drd} 4^{-/-}$mouse retina at ZT 4 and ZT 16 compared with WT controls. Basal and $\mathrm{Ca}^{2+} / \mathrm{CaM}$-stimulated adenylyl cyclase activities were determined in retinal membranes as described in Materials and methods. ZT 4 groups: $\mathrm{Ca}^{2+} / \mathrm{CaM}-$ stimulated adenylyl cyclase activity was significantly increased in WT samples $(* \mathrm{P}<$ 0.001 ), however when comparing stimulated groups, $\operatorname{Drd4^{-/}}$ samples failed to reach comparable WT levels of enzyme activity $(* * \mathrm{P}<0.001)$. Basal activity was significantly lower in $\mathrm{Drd} 4^{-/-}$samples compared to WT controls, but a significant increase is also observed between the basal and $\mathrm{Ca}^{2+} / \mathrm{CaM}$-stimulated in the $\operatorname{Drd} 4^{-/-}$samples (***P < 0.05). ZT 16 group; $\mathrm{Ca}^{2+} / \mathrm{CaM}$-stimulated activity in WT samples showed a significant increase compared to basal levels $(* \mathrm{P}<0.001)$. $\mathrm{Ca}^{2+} / \mathrm{CaM}$-stimulated activity in $\mathrm{Drd} 4^{-/-}$ was significantly lower than those in WT controls $(* * \mathrm{P}<0.001)$. A decrease in basal activity between WT and $D r d 4^{-1-}$ is also observed $(* * * \mathrm{P}<0.05)$. ZT4 and ZT16 comparison: $\mathrm{Ca}^{2+} / \mathrm{CaM}$-stimulated adenylyl cyclase activity in membranes from WT mice is significantly higher at ZT 16 than at ZT $4\left({ }^{\#} \mathrm{P}<0.001\right)$, demonstrating a rhythm in cyclase activity. Conversely, there is no detectable difference in activity between the two time points in the $\mathrm{Drd4}^{-/-}$samples. All statistics were determined by three-way ANOVA and post-hoc Student-Newman-Keuls method, $n=6$ per group. 


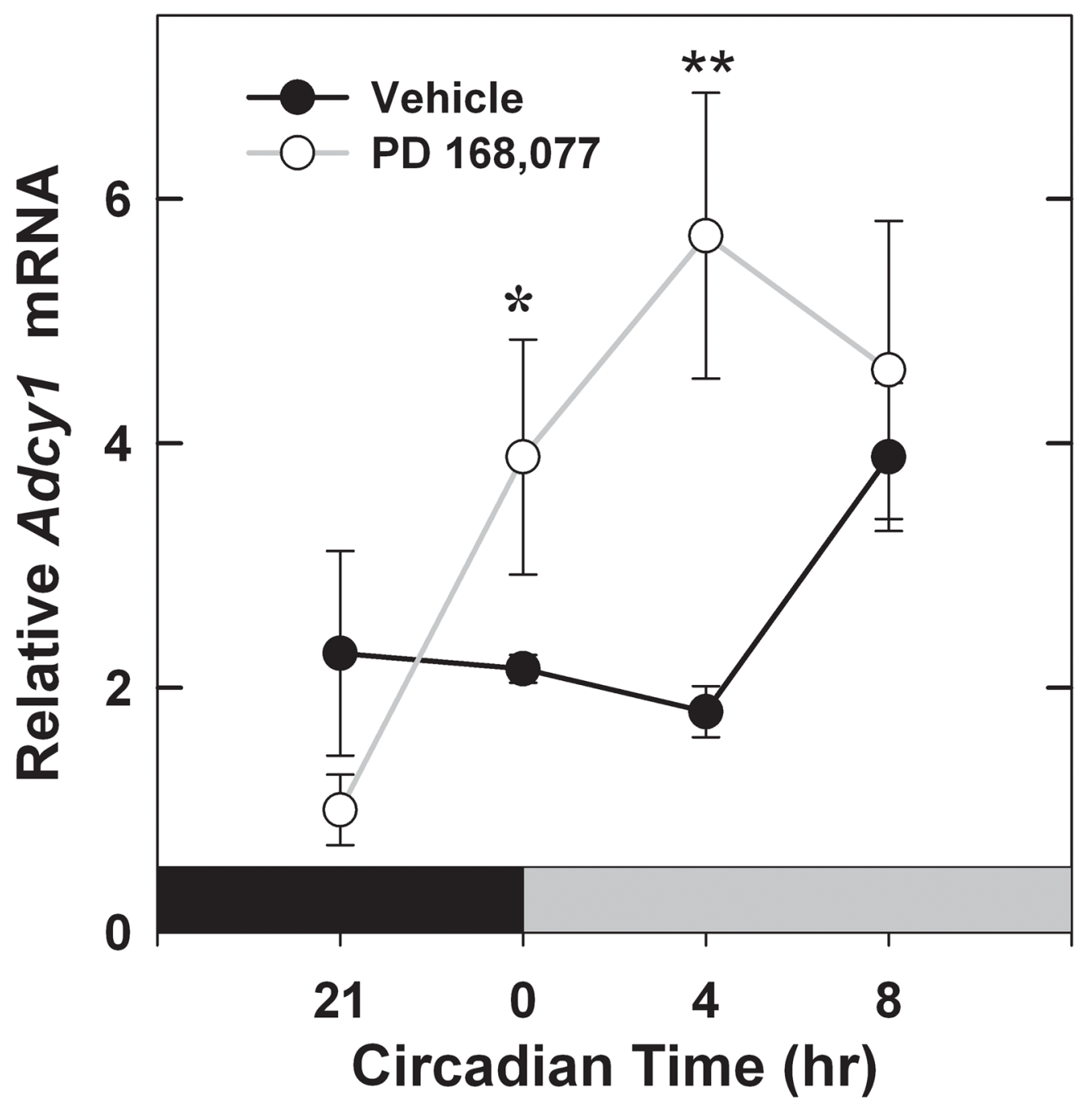

Fig. 7.

Effect of pre-dawn activation of $\mathrm{D}_{4} \mathrm{R}$ on the temporal expression pattern of Adcyl mRNA in mouse retina. Mice were injected at ZT 20 for three days with $1 \mathrm{mg} / \mathrm{kg}$ PD 168,077 or vehicle as described in Materials and methods. After the third injection, retinas were dissected during the following subjective night or subjective day in DD at the times indicated in the figure. In the PD 168,077 treatment group (open circles) a significant increase is observed from CT 21 to CT $0\left({ }^{*} \mathrm{P}=0.017\right)$ and to CT $4(* * \mathrm{P}=0.002)$. The treatment group peaks at CT 4 with values that are significantly higher than those of vehicle controls at that time $(\mathrm{P}=0.004)$. 